\section{A universidade brasileira em questão}

Hélgio TRINDADE (org.). Univesidade em númas na Reuública dos Professares Petrópolis/ Porto Alegre, Vozes/Cipede, 1999. 223 páginas.

\section{Sérgio de Azevedo}

O livro organizado por Hélgio Trindade discute 0 futuro da universidade brasileira de uma perspectiva interdisciplinar e comparativa, buscando romper com o paroquialismo desse debate por meio da análise de experiências internacionais. Ainda que o núcleo da reflexão seja a universidade pública brasileira, com ênfase no sistema federal de ensino superior, a coletânea propicia ao leitor um esboço do estado da arte desse debate também em nível internacional.

O livro apresenta quatro grandes seções: "Público e privado em questão?"; "Perspectiva internacional"; "Reformas ou contra-reformas?"; e "Naufrágio da universidade?", perfazendo um total de 16 artigos. No artigo de abertura, "Universidade, ciência e Estado", o organizador realiza um breve histórico da evolução da universidade desde a sua invenção no século XII até os dias atuais, terminando por analisar os impasses e desafios da universidade contemporânea, especialmente 0 decorrente da "contradição entre os cientistas que dependem crescentemente dos recursos do Estado mas não querem ser governados por ele e os governos que querem planejar a pesquisa e orientá-la para os setores economicamente mais promissores".

\section{Público e privadb em questão?}

0 primeiro artigo, "As universidades frente à estratégia do governo", também de autoria de Hélgio Trindade, objetiva discutir os pressupostos teóricos do projeto de reforma constitucional que pretende conceder autonomia às universidades públicas federais. Frisa 0 autor que, excetuando as estaduais paulistas, nunca as universidades públicas gozaram de autonomia administrativa e financeira, ainda que estas estejam previstas na
Constituição Federal de 1988. Trindade lembra também que, estimuladas pelos governos militares, as instituições privadas cresceram de forma acelerada em três décadas, passando de $40 \%$ das matrículas no ensino superior para cerca de $75 \%$ do total, apesar de $90 \%$ da pesquisa científica e tecnológica continuar sendo realizada pelo sistema público de ensino superior. A partir de uma ampla análise de experiências internacionais sobre processos de autonomia universitária, 0 artigo faz um exame crítico das propostas governamentais recentes sobre 0 tema e defende um processo de implementação incremental da reforma, sempre respaldado pela participação dos diversos atores envolvidos.

Em "O público e o privado na educação superior brasileira: fronteira em movimento?", Luiz Antônio Cunha mostra que, do período colonial aos nossos dias, têm ocorrido mudanças significativas entre o espaço público e o espaço privado. Segundo ele, a partir do golpe de 1964 os governos militares ampliaram de forma significativa 0 ensino superior no país, principalmente pela expansão das universidades federais e por uma extensa gama de incentivos à iniciativa privada. Por outro lado, o processo de democratização aumentou significativamente 0 controle administrativo e financeiro das universidades federais por parte da União, o que dificultou um crescimento maior dos seus cursos. O panorama atual é de larga hegemonia do setor privado no que concerne aos cursos de graduação, embora não se possa subestimar 0 importante setor de pós-graduação strido sensu, compreendendo 58 mil alunos, na sua esmagadora maioria lotados em instituições públicas e financiados por agências estatais.

Após fornecer um panorama do ensino superior no país, Luiz Antônio Cunha realiza análise detalhada das políticas para 0 setor público e daquelas voltadas para 0 setor privado. No que se refere ao primeiro, ressalta a forte heterogeneidade do sistema federal de ensino superior (algumas poucas universidades altamente produtivas e uma gama enorme de universidades onde ocorre um baixo tradeoff entre ensino e pesquisa). Também 0 ensino privado apresenta forte heterogeneidade, dividido entre instituições privadas no sentido 
estrito, de um lado, e instituições comunitárias, confessionais e filantrópicas, de outro. $\mathrm{O}$ autor finaliza 0 artigo referindo-se a uma convergência entre "'produtivistas' do setor público com os 'moralistas' do setor privado", sugerindo que a principal delimitação, hoje, não é mais "entre 0 estatal e o privado", mas aquela que demarca "a diferença específica entre a excelência e a mediocridade".

0 artigo de Dilvo Ristoff, "Privatização não faz escola", desmonta algumas das versões simplórias sobre as vantagens da privatização do ensino baseado na análise do caso norte-americano. Segundo 0 autor, diferentemente do Brasil, onde cerca de $75 \%$ dos estudantes de nível superior encontram-se matriculados em instituições privadas, nos Estados Unidos somente 3 milhões dos 14 milhões de universitários estão vinculados a organizações particulares. Ristoff destaca que, na segunda administração Clinton, a política de universalizar o acesso aos primeiros dois anos do nível superior (uma espécie de licenciatura curta) está se tornando realidade através não só da ampliação dos vários programas de bolsas e de crédito educativo tradicionais, mas sobretudo pela criação de dois novos programas em nível nacional, o "Hope Scholarship" e o "Tax Deduction", que estariam garantindo, atualmente, gratuidade completa nos colleges (primeira etapa da graduação) de pelo menos 37 dos 50 estados norte-americanos.

0 último artigo dessa seção, "Avaliação e privatização do ensino superior", de José Dias Sobrinho, discute a complexidade do processo de avaliação institucional das universidades. 0 autor faz uma forte e detalhada crítica à "avaliação eficientista", calcada na correlação entre custos e benefícios e centrada exclusivamente na busca de aumento da produção, na racionalização dos gastos e na otimização dos custos operacionais, ou seja, em uma perspectiva de racionalidade mercadológica na qual o investimento em educação é vinculado ao retorno econômico mais imediato e visível. José Dias Sobrinho deixa bem claro que não é contra a utilização desses índices per $ঙ$ mas adverte que, ao se restringir a esses indicadores quantificáveis, a avaliação deixa de lado a importância de processos que, por vezes, podem acarre- tar inúmeros resultados positivos somente percebidos a médio e longo prazos.

\section{Pespeetiva intemacional}

No artigo "Boyer Commission o modelo americano em debate", Dilvo Ristoff define as três características básicas do ensino superior norteamericano: orientação pública, estadualização administrativa e diversidade de objetivos acadêmicos. Os EUA, com uma população de 265 milhões de habitantes, possui quase 14 milhões de universitários - enquanto o Brasil, com uma população aproximada de 160 milhões de habitantes, tem somente 2 milhões de universitários. As instituições públicas americanas respondem por $78 \%$ da capacidade instalada do ensino superior no país. Em termos de financiamento da pesquisa, 60,4\% dos recursos são provenientes da União; 7,5\% dos governos estaduais e municipais; $18,1 \%$ de recursos próprios; $6,8 \%$ da indústria e 7,85\% de outras fontes. $\mathrm{O}$ autor chama a atenção para a pequena contribuição da indústria e para a forte participação da União em um país onde não há universidades federais. 0 mesmo ocorre em relação às bolsas de estudos, uma vez que a participação federal deverá ultrapassar $85 \%$ do total dos recursos após a implementação dos novos programas federais em curso. Ristoff ressalta ainda que uma das peculiaridades do sistema universitário americano é ter por base um tripé, com divisões de trabalho bem definidas: (1) universidades de pesquisa, com cursos de pós-graduação, altos investimentos em laboratórios e bibliotecas e corpo docente altamente qualificado; (2) universidades de ensino, que se dedicam a cursos de graduação tradicionais; (3) collegges (pós-secundários profissionalizantes), que oferecem cursos de dois anos voltados para atender as demandas operacionais imediatas do setor técnico e produtivo.

Apesar de todas essas conquistas, um estudo governamental recente conhecido como Relatório Boyer mostra o estado precário dos cursos de graduação das universidades de elite norte-americanas, que não usufruem de maneira adequada da rica infra-estrutura disponível e do corpo de professores altamente qualificados. Como alternativa, 
o documento propõe um novo modelo de ensino nessas universidades, "que efetivamente integre a experiência da graduação aos programas de mestrado e doutorado e aos trabalhos de pesquisa".

No artigo "Rappart Attalli: bases da reforma do ensino superior francês", Hélgio Trindade analisa propostas inovadoras dentro da tradição francesa. A França possui 87 universidades públicas e 92 institutos universitários tecnológicos que, juntos, absorvem cerca de $61 \%$ dos estudantes que concluem 0 segundo grau. Além desses cursos, há também as famosas "grandes édes", instituições públicas especializadas, altamente prestigiadas, onde predomina um recrutamento extremamente seletivo e socialmente elitizado. Segundo o Relatório Attalli, elaborado por uma equipe de especialistas, apesar da grande expansão do sistema de ensino superior francês ao longo das últimas décadas, este paulatinamente se tornou confuso, burocrático e gerador de desigualdades. 0 artigo faz uma análise detalhada das propostas apresentadas, mostrando que a idéia central é buscar uma reaproximação entre os dois sistemas (universidades e "grandes édes") e uma nova forma de estruturação do ensino superior francês, em moldes semelhantes ao padrão anglo-saxão (master degee e Ph.D.). A perspectiva de longo prazo seria a construção de um "modelo europeu" capaz de superar o sistema burocrático tradicional sem, no entanto, se submeter à lógica do mercado.

0 artigo "Dearing Repat: novas mudanças na educação superior inglesa?", de Valdemar Sguissardi, propõe-se a estudar o modelo inglês, apresentado por alguns especialistas como uma possível inspiração para os chamados "países emergentes", dentre os quais se incluiria o Brasil. A discussão das perspectivas do sistema de pesquisa e ensino superior inglês toma como referência 0 chamado "Deaning Repat", relatório elaborado por uma comissão formada por representantes das universidades e de empresas privadas, ainda durante o final do governo conservador (1996), por iniciativa do parlamento britânico. 0 artigo começa afirmando que, diferentemente da maioria dos países desenvolvidos da Europa O cidental, o sistema inglês é formado inteiramente por instituições privadas que, entretanto, têm cerca de $80 \%$ dos seus orçamentos financiados pelo Estado. No pósguerra, 0 sistema teria passado de um sistema elitista para um sistema aberto a novos grupos sociais, através da criação dos chamados Politécnicos (polytedhics). Este sistema binário vai existir até 1992, quando o governo conservador realiza a unificação do mesmo.

Segundo 0 autor, as reformas empreendidas durante 0 período Thatcher orientaram-se fundamentalmente pelo enfoque mercadológico. Se antes cabia às universidades privadas definir a forma de emprego dos fundos governamentais, inclusive os destinados à pesquisa, com as novas políticas incentivos financeiros foram utilizados para induzir as instituições a aplicarem a maior parte dos recursos nas áreas consideradas estratégicas pelo governo. Essas políticas tiveram vários efeitos perversos (corte de verbas, diminuição dos salários, perda da estabilidade do emprego, aumento das anuidades estudantis etc.) mas também contabilizaram vários resultados positivos (ampliação do número de vagas, redução do custo per capita dos alunos, maior captação de recursos junto ao setor privado, aumento do desempenho das pesquisas etc.). Os autores do "Dęing Repat" mostram preocupação com os impactos negativos para a competitividade internacional do país decorrentes das reduções previstas nos investimentos para a educação superior nas próximas duas décadas, e ressaltam a necessidade de se pensar em novas fontes de financiamento para 0 terceiro grau. Frisam que 0 ensino deve responder às necessidades do mercado de trabalho, o que inclui o desenvolvimento de habilidades gerais, em decorrência da rápida transformação tecnológica. D estacam, ainda, a importância da integração do ensino superior com o desenvolvimento local e regional. Como forma de diminuir o elitismo do ensino superior, sugere-se a sua massificação. A proposta é que nos próximos 20 anos o percentual atual de $32 \%$ de diplomados - em relação aos concluintes do ensino secundário - se eleve para cerca de $45 \%$.

A questão mais polêmica refere-se a quem deve pagar pelo ensino superior. Os dados do Relatório, relativos ao biênio 1995-1996, indicam que, no que diz respeito ao ensino superior stricto 
sensu, os fundos públicos arcaram com $78,6 \%$ do custo total, os alunos ou suas famílias com 7,6\%, e os $13,9 \%$ restantes foram financiados por outras fontes. No que diz respeito ao financiamento da pesquisa, os fundos públicos participaram com $74,3 \%$, a indústria e o comércio, com $7,2 \%$, as doações (dharities), com $14 \%$, e $4 \%$ veio de outras fontes. 0 Relatório recomenda que 0 percentual de participação do setor público aumente na mesma proporção do Produto Interno Bruto e que os estudantes, através de anuidades ou de empréstimos reembolsáveis, arquem com 0 equivalente a $1 / 4$ dos custos dos respectivos cursos, 0 que corresponderia a um pagamento médio anual da ordem de U\$1.620. 0 autor conclui afirmando que o governo trabalhista acatou a maior parte das sugestões do Relatório, excetuando as referentes ao pagamento das anuidades, às quais contrapôs uma proposta mais branda em relação aos setores de menor renda.

0 artigo "Unesco e os cenários da educação superior na América Latina", de Hélgio Trindade, procura relacionar características das propostas governamentais de reforma do ensino superior no Brasil com processos similares de outros países latino-americanos. O autor destaca que as propostas da Unesco se chocam com as políticas do Banco Mundial para a região que vêm sendo implementadas, em ritmo diferenciado, por diversos países latino-americanos. A diferença central entre as propostas da Unesco e do Banco Mundial seria que, para a primeira, o Estado deve se comprometer explícita e firmemente com 0 financiamento estratégico de médio e longo prazos da pesquisa e do ensino superior, posição hoje majoritária na maioria dos países desenvolvidos, a começar pelos EUA, que rejeitaram a receita "thatcheriana". Em contrapartida, 0 autor percebe que parte considerável dos governos latino-americanos, a partir das orientações do Banco Mundial, encontra-se na contramão da história, sob a racionalização simplória de que "o financiamento estatal das universidades é um forma regressiva de distribuição que favorece os grupos de renda mais alta". Segundo Hélgio Trindade, a retórica governamental e a recente reformulação do sistema de avaliação do MEC apontam para um cenário possível onde as universidades federais autônomas mais qualificadas - junto com a USP e a Unicamp - tornar-seão os grandes centros de pesquisa, de formação de quadros e de pós-graduação. As demais universidades federais não autônomas continuarão submetidas aos controles tradicionais e se dedicaram prioritariamente ao ensino de graduação. Ressaltese, ainda, que nesse desenho institucional caberia às universidades, centros e faculdades privadas função primordial na expansão dos cursos de graduação .

\section{Reformas al contra-reomas?}

No artigo de Luiz Antônio Cunha denominado "Reforma universitária em crise: gestão, estrutura e território", o primeiro assunto tratado diz respeito às especificidades das universidades em relação a outros tipos de organizações e à inadequação da aplicação a elas de métodos de gestão administrativa calcados em paradigmas empresariais tradicionais. Argumenta 0 autor que, como 0 objetivo da universidade é a produção de novos conhecimentos, há necessidade de convivência institucional entre grupos com perspectivas alternativas, não fazendo sentido imaginar nenhum tipo de sistema monolítico de poder.

Após apresentar um sucinto histórico da formação das universidades brasileiras, o artigo informa que essa estruturação ocorreu fundamentalmente por duas formas: pela fragmentação das antigas Faculdades de Filosofia, Ciências e Letras ou pela substituição das faculdades, escolas e institutos pelos centros. Depois de discutir em detalhes toda essa trajetória, o autor sugere que, atualmente, a maioria das universidades federais pode ser enquadrada em quatro modelos básicos: "(1) a agregação dos departamentos em alguns poucos centros; (2) a reunião dos departamentos em número maior de institutos, faculdades ou escolas; (3) a ligação dos departamentos diretamente à administração superior, sem instância intermediária alguma; (4) a superposição de centros às faculdades, aos institutos e às escolas". Segundo Luiz Antônio Cunha, a disputa entre os partidários da estrutura baseada em "unidades" e aqueles que defendem os "centros" acabou sem vencedores em um grande número de universi- 
dades que apresentam um formato institucional híbrido.

O autor também realiza uma primorosa análise da divisão interna do trabalho universitário decorrente da Lei ip 5.540, de agosto de 1968, que extingue as cátedras e implanta o regime de departamentos e a divisão dos cursos de graduação entre ciclo básico e profissionalizante, com o surgimento dos colegiados de cursos. São relatadas diversas contradições, conflitos e dificuldades na interação entre os diversos atores.

$\mathrm{O}$ último grande tema tratado pelo artigo diz respeito às formas de organização territorial das universidades. 0 autor lembra que 0 campus se generalizou de tal forma no país, a partir dos anos 60 e 70, que mesmo instituições aspirantes a se tornarem universidades por vezes iniciavam a construção do mesmo antes de possuírem infraestrutura acadêmica e corpo docente compatível com 0 status demandado. 0 autor faz várias críticas ao modelo de campus ressaltando, entre outros, o excessivo custo das obras e as dificuldades de deslocamento para parte considerável dos corpos docente e discente e dos funcionários.

No artigo "Concepções de universidade e de avaliação institucional", José Dias Sobrinho resgata e aprofunda algumas de suas reflexões sobre "avaliação institucional" esboçadas no artigo já citado ("Avaliação e privatização do ensino superior") e realiza um contraponto entre as posições conflitantes do Banco Mundial e da Unesco, na mesma linha do artigo de Hélgio Trindade. Dias Sobrinho destaca que as avaliações não podem ser entendidas como a aplicação de um conjunto de técnicas neutras. Elas estão sempre inseridas em um contexto social marcado por valores que lhes oferecem certa consistência e legitimidade. $\mathrm{Na}$ atualidade, o centro do debate epistemológico se daria entre visões diferentes e mesmo antagônicas de "eficiência" e "qualidade" para o ensino superior (por exemplo, Banco Mundial vesus Unesco). Dependendo do modo como se entende esses conceitos, chega-se a concepções distintas de universidade.

$O$ artigo "A autonomia segundo o MEC: fragilidade política e ambigüidade conceitual", do professor Hélgio Trindade, faz um balanço sucinto das iniciativas políticas do Ministério da Educação para 0 ensino superior, mostrando sua debilidade diante dos "centros duros" de poder do governo, particularmente em relação à área econômica. Devido ao histórico de fragilidade institucional do Ministério, 0 autor mostra-se bastante cético acerca do novo documento do MEC sobre o tema. Este é analisado detalhadamente, sendo mostradas suas várias incoerências conceituais, dentre as quais 0 autor destaca a de confundir "autonomia" com "contrato de desenvolvimento institucional". Segundo Trindade, $0 \mathrm{MEC}$, na impossibilidade de viabilizar uma verdadeira "autonomia" para todas as universidades federais - devido à sua fraqueza institucional, aliada à não prioridade dessa questão na agenda da União - , ardilosamente acena com uma fórmula inovadora que buscaria "salvar do dilúvio algumas das grandes universidades federais".

\section{Naufrágio da universidade?}

0 artigo "A universidade pública no Brasil: identidade e projeto institucional em questão", escrito por Afrânio Mendes Catani em parceria com João Ferreira de Oliveira, discute os elementos condicionantes do processo de transição institucional e a formação de possíveis novas identidades. Para os autores, o processo de transformação por que passa a universidade pública brasileira particularmente as instituições federais de ensino superior - seria decorrência da confluência de diversos fatores. Do ponto de vista institucional, a asfixia paulatina das universidades federais decorrente dos crescentes cortes de recursos da União vem levando à utilização de diversas estratégias de sobrevivência, dentre elas a busca de recursos alternativos junto ao setor privado. No que se refere à sua interação com a sociedade, 0 atual processo de rápida transformação tecnológica e de circulação do conhecimento exige da universidade, segundo os autores, uma "dispersividade e multidiversidade de tarefas e ações". Por último, a busca de maior legitimidade institucional tem induzido a maioria dessas instituições (particularmente as de menor porte) a procurar uma maior aproximação com 0 setor produtivo e com a 
comunidade local. A resultante desse processo é a paulatina diferenciação das universidades em virtude da diversidade de projetos institucionais em curso, mesmo sem a existência de um processo real de autonomia institucional. A partir da análise das políticas governamentais para as instituições federais de ensino superior, vislumbra-se um cenário futuro onde teríamos, de um lado, as grandes universidades, com maior apoio de fundos públicos, realizando pesquisas de ponta e responsáveis pelos cursos de pós-graduação strico sensu mais prestigiados e, de outro, as instituições de médio e pequeno portes - altamente diversificadas e especializadas regionalmente - com maior ênfase nos cursos de graduação e menor respaldo governamental.

0 artigo "Crise no financiamento das instituições federais de ensino", de Nelson Cardoso Amaral, caracteriza-se pela riqueza e clareza de informações e por uma análise bastante didática. 0 autor lembra que, por determinação constitucional, cabe à União arcar com $20 \%$ do total de investimentos em educação, cabendo aos estados e municípios os $80 \%$ restantes. Assim sendo, não se sustenta a tese de que a falta de recursos para 0 primeiro e segundo graus seria devida aos gastos da União com o ensino público de nível superior. Os recursos do erário público são divididos em duas grande rubricas, uma para pagamento de pessoal, que nos últimos anos engloba cerca de $94 \%$ do total, e outra para os custos de manutenção e investimentos, que se restringe a aproximadamente 6\%. Por outro lado, no período 1995-99, do total de impostos vinculados à educação, houve um decréscimo de quase $5 \%$ daqueles destinados às instituições federais de ensino superior. Nesse mesmo período, houve também uma queda no percentual do Produto Interno Bruto gasto com essas instituições, que passa de $0,79 \%$ para $0,61 \%$. Apesar dos índices mencionados, outros indicadores quantitativos levantados pelo autor sugerem um aumento da eficiência global do sistema federal de ensino superior nos sete primeiros anos da década de 90, decorrente do crescimento expressivo do número de estudantes de graduação e de pós-graduação e de teses e dissertações defendidas. Esses dados, no meu entender, demandariam uma discussão mais acurada do "sucateamento" das instituições federais de ensino superior, possivelmente mediante a incorporação de outras variáveis intervenientes envolvidas no processo.

No artigo "A tríplice crise da universidade brasileira", Dilvo Ristoff afirma que a universidade brasileira enfrenta hoje três crises: a financeira, a do elitismo e a do modelo. No que diz respeito à questão financeira, o autor busca mostrar a miopia do Estado brasileiro em procurar resolver questões financeiras de curto prazo por meio da diminuição do investimento público no ensino superior. Com base em exemplos interessantes de estudos realizados por economistas em diversos estados norteamericanos, Ristoff mostra que o investimento no ensino superior apresenta, a médio e longo prazos, um retorno em termos tributários muito acima das taxas médias de mercado.

A segunda crise diz respeito à nossa tradição elitista e à resistência implícita ou explícita à massificação do ensino superior. O Brasil possui apenas $10 \%$ da população na faixa etária do ensino superior cursando o terceiro grau, índice muito abaixo do encontrado nos países desenvolvidos e mesmo em nossos vizinhos latino-americanos. A terceira crise seria do nosso modelo, defasado diante da atual conjuntura nacional e internacional. Segundo o autor, seria necessário um novo modelo capaz de, concomitantemente, enfrentar três demandas relevantes e legítimas: (1) garantir os interesses pelo avanço desinteressado da ciência (demanda da comunidade científica); (2) responder aos interesses estratégicos e conjunturais do desenvolvimento econômico-social (demanda dos diferentes níveis de governo); (3) permitir a uma grande massa de excluídos 0 acesso ao ensino superior, visto como uma das alternativas de mobilidade social (demanda da população). Ristoff reconhece que essas expectativas não são necessariamente excludentes, mas adverte que deve haver cuidado para que, ao se tentar responder a uma delas, não se inviabilize as outras.

Finalmente, 0 autor explicita um novo formato institucional que se vem firmando como dominante na maioria dos países desenvolvidos. Tratase de hierarquizar 0 ensino em três níveis: 0 primeiro seria formado pelas grandes universida- 
des voltadas "para 0 avanço desinteressado da pesquisa" e para a maioria dos cursos de pósgraduação; 0 segundo, pelas universidades públicas ou privadas - que priorizariam os cursos de graduação, objetivando responder às demandas do mercado e do Estado, realizando também algumas pesquisas aplicadas e cursos de pós-graduação profissionalizantes; 0 terceiro nível seria composto por numerosas e diversificadas instituições pós-secundárias (públicas e privadas), do tipo college norte-americano, especializadas em cursos de caráter profissionalizante.

No último artigo dessa seção, "A universidade em ruínas", escolhido também como título da coletânea, Marilena Chauí realiza uma dura crítica aos pressupostos do modelo de universidade defendido pelas correntes neoliberais e que estaria também presente na proposta de reforma do Estado no Brasil. A proposta neoliberal para o ensino superior, segundo ela, é transformar a universidade pública em uma "organização social", regida basicamente por meio de contratos de gestão com 0 Estado. Após realizar uma síntese do surgimento e crise do udfare state no mundo ocidental e do crescimento e hegemonia do pensamento neoliberal, a autora mostra que a universidade, ao se balizar pelas normas do mercado, perde sua marca registrada, ou seja, a autonomia. Chauí lembra que a universidade moderna legitimou-se a partir da conquista da autonomia frente ao Estado e à religião, baseada "na idéia de um conhecimento guiado por sua própria lógica, por necessidades imanentes a ele, tanto do ponto de vista de sua invenção ou descoberta como de sua transmissão". Nesse sentido, a metamorfose operada pela concepção neoliberal é a de tentar transformar a universidade - tradicionalmente uma "instituição social" - em uma "organização", ou seja, em uma entidade particular e isolada onde a eficiência é medida em relação ao seu desempenho perante suas concorrentes. A uma organização não cabe refletir sobre sua própria existência, seu papel dentro da sociedade, sobre sua produção e para quem se produz, questões centrais da instituição universitária Assim, enquanto a instituição social é voltada para a universalidade, ou seja, tem a sociedade, seus valores e paradigmas como refe- rência, a organização tem a si mesma como referência, numa lógica de mercado que valoriza 0 quanto se produz, em quanto tempo e qual o custo do que é produzido. Ao voltar-se para si mesma, esse tipo de "universidade operacional" perderia legitimidade pública, seu papel social, e acarretaria deformações de suas atividades fins. A formação acadêmica correria 0 risco de se transformar em transmissão de conhecimentos e adestramento, e a pesquisa, de ser reduzida a "uma estratégia de intervenção e de controle de meios ou instrumentos para a consecução de um objetivo delimitado", perdendo-se 0 significado do seu objetivo mais amplo de reflexão crítica, de questionamento do status qua de descoberta, de tentar compreender a realidade a partir da elaboração de "sínteses abertas que suscitem a interrogação" e novas buscas.

\section{SÉ RGIO DE AZEVEDO é professor da PUC-MG.}




\section{Dois estudos de mobilidade social no Brasil}

José PASTORE e Nelson do VALLE SILVA. Mdalidade sodal mo Brasil. São Paulo, Macron Books, 2000. 98 páginas.

Maria Celi SCALON. Mdailidade soial mo Brasil: padrões e tendânias Rio de Janeiro, Revan, 1999. 190 páginas.

\section{Carlos Antonio Costa Ribeiro}

Há pelo menos dois bons motivos para recebermos com entusiasmo o novo livro de José Pastore e Nelson do Valle Silva e o livro de Maria Celi Scalon. Primeiro, os autores descrevem cuidadosamente características e mudanças na estratificação social brasileira. Segundo, os estudos abrem a possibilidade de novos debates sobre abordagens metodológicas e teóricas de extrema importância para 0 estudo da mobilidade social na sociologia contemporânea. Apesar do mesmo título e de usarem metodologia semelhante, os livros seguem perspectivas teóricas distintas e tratam de temas diferentes. Leitores que fizerem um contraste entre eles, e não se intimidarem por números e estatísticas, aprenderão muito sobre metodologia quantitativa, sobre sociologia e sobre o Brasil.

O livro de Pastore e Valle Silva adota uma perspectiva teórica que pode ser definida como "estudos da mobilidade de status" ou de "hierarquias socioeconômicas". Aproxima-se, portanto, da tradição iniciada pelos sociólogos norte-americanos Peter Blau e Otis Dudley Duncan (1967) com o objetivo de analisar as mudanças na mobilidade social e na estrutura ocupacional brasileira ocorridas entre as décadas de 1970 e 1990. O que caracteriza esta opção teórica mais claramente é a escolha de um "esquema de classes", ou melhor, de "grupos de status" ordenados hierarquicamente, de acordo com características de renda e educação, em seis categorias: (1) baixo-inferior; (2) baixo-superior; (3) médio-inferior; (4) médio-médio; (5) médio-superior e (6) alto. Ao escolher esta classificação hierárquica de status os autores estão definindo a estrutura social como uma hierarquia.
Talvez faça sentido pensar o status social como definido hierarquicamente. Mas será que esta é a única alternativa?

Maria Celi Scalon propõe outra forma de estudar mobilidade social, baseada não mais no estudo de hierarquias de status, mas na "análise de classes" ou "mobilidade de classes", tal como definida pelo sociólogo inglês John H. Goldthorpe (1987). Desta perspectiva, seu livro busca não só descrever as barreiras de classe mais difíceis de serem transpostas, quanto discutir os efeitos da interação entre gênero e classe nos padrões de mobilidade social. Ao invés de "grupos de status" ordenados hierarquicamente entre baixo e alto, a autora elabora um mapa de nove classes sociais, que indicam posições distintas em uma estrutura de classes definida por diferentes condições de mercado e trabalho. Embora, por vezes, correspondam a diferentes níveis de renda e educação, estas classes são concebidas como ocupando posições distintas em uma estrutura relacional, ou seja, uma estrutura de classes baseada antes em oposições do que em hierarquias entre as classes. As classes utilizadas são: I - Profissionais; II Administradores e gerentes; III - Proprietários empregadores (urbanos); IV - Não-manual de rotina (em geral pessoal de escritório, vendas e comércio); V - Proprietários por conta própria (pequenos proprietários sem empregados); VI Manual qualificado; VII - Manual não-qualificado; VIII - Empregadores rurais; IX - Empregados (trabalhadores) rurais. $\mathrm{O}$ fato de a autora adotar uma perspectiva em que as classes são concebidas como fazendo parte de um "espaço relacional" significa que, para ela, a estrutura social está sendo definida antes por oposições de classe do que por hierarquias de status*

É importante ter em mente que há diferenças teóricas entre os dois livros, mas não precisamos exagerá-las. Não acho que uma perspectiva exclua

* Um debate relativamente recente na European Socido gical Review mostra a contemporaneidade das diferenças entre a perspectiva que propõe 0 estudo da mobilidade social no contexto de "hierarquias sociais" e a que privilegia "o contexto de classes". Veja, respectivamente, Hauser e Hout (1992) e Erickson e Goldthorpe (1992). 
a outra. Provavelmente ambas são verdadeiras. Em alguns momentos é válido falar em hierarquias, e em outros em oposições de classe. Na realidade, partidários de cada uma das duas perspectivas mencionam alguma forma de hierarquia ou de oposição de classes quando analisando estatisticamente os dados. Isto é verdade tanto para os estudos de Blau e Duncan (1967) e de Hout (1989), ambos partidários das hierarquias sociais, quanto para os estudos mais recentes de Goldthorpe e Erickson (1993) e de Wright (1997), partidários dos "esquemas relacionais de classes". Embora privilegiando uma ou outra perspectiva, todos estes autores fazem uso, em suas análises empíricas, ora de hierarquias, ora de oposições entre classes.

Apesar das diferenças teóricas, os dois livros baseiam suas análises em metodologia semelhante. Ambos descrevem taxas absolutas e relativas de mobilidade social. As taxas absolutas de mobilidade social são definidas por cálculos percentuais simples usando a tabela de mobilidade - tabelas cruzando ocupação do pai e ocupação do filho, e primeira ocupação e ocupação atual. As taxas relativas de mobilidade são derivadas de modelos estatísticos log-lineares aplicados às tabelas de mobilidade. Uma outra maneira de se entender a diferença entre taxas absolutas e relativas de mobilidade é pensar em termos de desigualdades de posição e de acesso ou oportunidade (ver Marshall e al., 1997). As mudanças ou diferenças nas taxas absolutas são indicadores da desigualdade de posições. Já as taxas relativas indicam 0 nível de desigualdade de acesso a estas posições.

Usando taxas absolutas de mobilidade, Pastore e Valle Silva mostram que em 1996 as pessoas estavam, em média, ocupando posições de status mais altas e melhores do que as posições que seus pais e as pessoas em geral ocupavam em 1973. Pode se dizer que, de uma maneira geral, as condições de vida, ou padrões de vida das pessoas melhoraram. Mais gente tem acesso a serviços de saúde, educação, moradia etc. de melhor qualidade. Em contraste, as desigualdades de acesso ou oportunidade, definidas pelas taxas relativas de mobilidade social, não mudaram no Brasil, ou mudaram muito pouco. 0 acesso às melhores posições de status, e portanto às melhores condi- ções de vida, continua sendo tão desigual em 1996 quanto era em 1973.

Usando a mesma distinção entre taxas absolutas e relativas de mobilidade, ou entre desigualdades de posição e de acesso, Scalon nos mostra que homens ocupam posições mais vantajosas do que mulheres na estrutura de classes - por exemplo, são mais freqüentemente proprietários empregadores. Em contraste, homens e mulheres têm chances de acesso semelhantes quando pertencem à mesma classe social, ou seja, as chances de acesso a melhores posições na estrutura de classes são definidas antes pelas classes de origem do que pelo gênero das pessoas.

Para além das diferenças teóricas e das semelhanças metodológicas, o que torna os livros leitura fundamental para qualquer cientista social interessado no Brasil é a riqueza das informações e análises empíricas apresentadas. Mas quais são os objetivos e principais conclusões dos autores?

O objetivo de Pastore e Valle Silva é fazer um exame da dinâmica da mobilidade social dos homens chefes de família no país entre 1973 e 1996, tendo como base de dados as respectivas PNADs.* Os autores chegam a uma conclusão semelhante àquela que Pastore havido chegado no seu livro de 1981, baseado em dados de 1973: há muita mobilidade e desigualdade social no Brasil. 0 fato de a estrutura social brasileira ser muito desigual e ter mudado muito rapidamente, passado de uma sociedade essencialmente agrária para uma sociedade industrial em poucas décadas, implicou uma completa reordenação da estrutura ocupacional do país. Em uma geração, muitos postos de trabalho no setor primário (onde estão as ocupações mais baixas na hierarquia social) foram extintos e novas posições nos setores industrial e de serviços foram criadas. Conseqüentemente, muita gente deixou de seguir a atividade de seus pais para ingressar em carreiras

* As PNADs - Pesquisa Nacional por Amostragem Domiciliar - são coletadas anualmente desde 1967 pelo Instituto Brasileiro de Geografia e Estatística (IBGE). Os microdados das PNADs podem ser adquiridos, em forma de CD-disc, por qualquer pesquisador interessado. Informações sobre mobilidade social podem ser encontradas nas PNADs de 1973, 1976, 1982, 1988 e 1996. 
novas e geralmente de maior status, uma vez que as posições na base da hierarquia de status foram extintas. Em suma, houve muita mobilidade social devido a mudanças na estrutura ocupacional, muita "mobilidade estrutural" - o que, aliás, é comum em sociedades em desenvolvimento, como é o caso do Brasil. Contudo, as trajetórias de mobilidade social são caracterizadas pela curta distância. As pessoas subiram na hierarquia socioeconômica mas subiram, em geral, para o degrau imediatamente superior ao que seus pais ocupavam. Houve relativamente pouca gente com origem nos grupos de status mais baixos que conseguiu chegar aos grupos mais altos. Por exemplo, só $2 \%$ das pessoas cujos pais estavam no grupo de status baixo-inferior (trabalhadores rurais) chegaram a ocupar posições no grupo de status alto. Se pudesse descrever da forma mais sintética possível as conclusões do livro, eu diria: muita mobilidade, de curta distância, e muita desigualdade são as características da estratificação por status brasileira.

Obviamente, o livro não pode ser resumido de forma tão drástica. Analisemos, pois, especificamente, os diversos temas tratados, que podem ser assim classificados: (1) padrões de início de carreira e a relação entre educação e mobilidade social; (2) mobilidade intergeracional; (3) mobilidade intrageracional; (4) cor e mobilidade social.

(1) Os padrões de início de carreira e educação são analisados seguindo a perspectiva dos "estudos de realização de status ou socioeconômica". Usando modelos de regressão linear, os autores chegam à conclusão de que o grupo de status do pai, o nível de educação do pai e a moradia em área rural são os principais determinantes da idade do início de carreira. Por exemplo, em média, filhos de médicos (grupo de status alto) entram no mercado de trabalho com 21 anos, ao passo que filhos de trabalhadores rurais (grupo de status baixo-inferior) que sejam analfabetos começam a trabalhar, em média, com 9,7 anos de idade. Status e educação do pai também são apontados como os principais determinantes dos anos de estudo que os homens brasileiros conseguem completar. Finalmente, conclui-se que quanto mais alto o status do pai e seu nível de educação, mais alto 0 status da primeira ocupação do filho.
(2) Para estudar os padrões de mobilidade intergeracional entre 1973 e 1996, os autores analisam as taxas absolutas e relativas de mobilidade. Embora baseadas em cálculos percentuais simples, as taxas absolutas de mobilidade, quando interpretadas com cautela, podem revelar características interessantes da mobilidade social. Os índices de mobilidade absoluta utilizados são os seguintes: (a) fluxos de saída ou percentuais das linhas da tabela de mobilidade (ou seja, o destino social das pessoas medido pelo status adquirido); (b) fluxos de entrada ou percentuais das colunas da tabela de mobilidade (ou seja, a origem das pessoas medida pelo status de origem ou do pai); e (c) mobilidades geral, estrutural e de circulação (definidas de acordo com cálculos percentuais usando os dados da tabela de mobilidade). Em contraste, as taxas relativas de mobilidade são definidas pelas chances relativas de acordo com os modelos estatísticos log-lineares. As chances relativas (ou odds ratio) são derivadas do grau de associação entre origem e destino ocupational.

0 balanço dos autores usando taxas absolutas de mobilidade mostra que houve melhorias nos padrões de mobilidade absoluta entre 1973 e 1996. Em outras palavras, a industrialização e a expansão da economia brasileira criaram mais postos de trabalho nas ocupações dos grupos de status mais elevados e diminuíram o número de postos de trabalho nas ocupações de status baixo (principalmente na agricultura). Conseqüentemente, houve mobilidade para cima, porque havia mais vagas em cima na geração dos filhos do que em suas origens, tal como definidas pelo status dos pais - houve, portanto, muita "mobilidade estrutural".* Além disso, mais gente mudou de classe - e mais freqüentemente para cima - em 1996 do que em 1973.

Em contraste, as taxas de mobilidade relativa encontradas nos modelos log-lineares indicam "grande estabilidade temporal" (p. 71). O caso brasileiro confirma a hipótese de que, em sociedades industriais, as taxas de mobilidade relativa tendem a ser

* O conceito de "mobilidade estrutural" foi veementemente criticado por Sobel (1983 e 1998). Em minha própria pesquisa estou desenvolvendo estas críticas para analisar os dados brasileiros. 
estáveis ao longo do tempo - hipótese proposta por Featherman, Jones e Hauser (1975) e reformulada por Erickson e Goldthorpe (1993). Dizer que as taxas de mobilidade relativa ficaram estáveis significa dizer, por exemplo, que entre 1973 e 1996 as chances de um filho cujo pai era do grupo de status alto permanecer no mesmo grupo do pai continuaram muito maiores do que as chances de um filho cujo pai era do grupo de status baixo-inferior alcançar o grupo de status mais alto. Em outras palavras, as chances do filho de um profissional liberal seguir os passos do pai são muito maiores do que as chances de um filho de trabalhador rural se tornar um profissional liberal. Este tipo de chances relativas não mudou nada entre 1973 e 1996.* Apesar de chegarem a esta conclusão, os autores sugerem que algumas melhoras podem ter ocorrido, embora não apresentem análises estatísticas que poderiam testar a possibilidade de mudança sugerida. Quanto a este aspecto, estudos metodologicamente mais sofisticados são necessários.

(3) A mobilidade intrageracional ou de carreira é a mobilidade entre a primeira ocupação e ocupação atual. 0 estudo deste tipo de mobilidade é importante porque permite descrever as trajetórias que vão da origem (ocupação do pai), passando pela primeira ocupação do filho, e chegando ao destino (ocupação atual do filho). Neste sentido, pode haver tanto trajetórias de ascensão e de descida na escala de status quanto trajetórias de ascensão depois descida e finalmente ascensão, ou vice-versa. Ao analisar a mobilidade intrageracional usando modelos de regressão, Pastore e Valle Silva mostram que as trajetórias são geralmente de ascensão para os indivíduos que começam suas carreiras em posições de status mais baixas, e de pequena mobilidade descendente para pessoas iniciando a carreira em posições altas. No entanto, os autores afirmam que 0 padrão geral de mobili-

* Embora as chances relativas, e portanto as desigualdades de acesso, tendam a ser constantes ao longo do tempo, há países onde este tipo de desigualdade vem diminuindo. Por exemplo, na França durante os últimos 40 anos houve uma diminuição de cerca de $20 \%$ na desigualdade de acesso ou oportunidade medida de acordo com modelos log-lineares (Erickson e Goldthorpe, 1993). dade intergeracional não é afetado pela mobilidade de carreira.

(4) Finalmente, Nelson do Valle Silva contribui com um último capítulo sobre mobilidade social e cor das pessoas. Ele chega à conclusão de que pretos e pardos têm menos chances de mobilidade ascendente do que brancos, e de que esta desvantagem é ainda maior quando se observa os padrões de aquisição educacional - "0 núcleo duro da desvantagem que pretos e pardos sofrem se localiza no processo de aquisição educacional" (p. 96). Em suma, pretos e pardos têm menos chances de ascensão porque têm menos chances de adquirir melhores níveis educacionais.

Em contraste ao livro de Pastore e Valle Silva, o livro de Scalon se alinha à perspectiva da "análise de classes" e usa os dados da PNAD de 1988. De acordo com tal perspectiva teórica, os estudos de mobilidade social são centrais para descrever tanto a formação e dissolução de classes sociais (descritas por taxas absolutas de mobilidade), quanto a "fluidez" ou rigidez da estrutura de classes (descrita pelas taxas relativas de mobilidade). Aliás, a autora nos ensina muito sobre teorias de mobilidade social e quem estiver interessado não pode deixar de ler os primeiros capítulos do livro.

Nestes capítulos Scalon faz um balanço crítico da literatura sociológica contemporânea sobre mobilidade social. Mostra que os estudos de mobilidade social desempenham papel fundamental não apenas na descrição de desigualdades em sociedades industriais, mas também na redefinição de questões centrais seja na teoria sociológica marxista, na weberiana, na de estratificação social, ou em geral. Um bom exemplo da inovação teórica ligada aos estudos de mobilidade social é 0 conceito de "estruturação" da sociologia de Anthony Giddens, formulado, inicialmente, para descrever a formação de classes através da mobilidade social (Giddens, 1973). A combinação desta discussão da teoria da mobilidade social com a análise sofisticada de temas substantivos torna o livro de Maria Celi Scalon leitura obrigatória para qualquer cientista social.

Os objetivos das análises empíricas são: (1) descrever a desigualdade de posições entre homens e mulheres (usando taxas absolutas de mobi- 
lidade); (2) discutir três hipóteses clássicas dos estudos de mobilidade ("fechamento social", "zona de contenção" e "contramobilidade"); e (3) elaborar um modelo log-linear "topológico" para analisar o grau de "fluidez" ou rigidez da estrutura social brasileira, bem como verificar se os padrões relativos de mobilidade são distintos para homens e mulheres.

(1) Para descrever a desigualdade de posições entre homens e mulheres, a autora lança mão dos mesmos índices de mobilidade absoluta que são usados por Pastore e Valle Silva. Mas, ao invés de descrever mudanças ou continuidades ao longo do tempo, Scalon centra-se na descrição não ape nas da diferença entre as posições que homens e mulheres ocupam na estrutura de classes, mas também dos respectivos índices de mobilidade absoluta. De acordo com os dados de 1988, homens e mulheres ocupam posições bastante desiguais na estrutura de classes. Por exemplo, as mulheres tendem a se concentrar na classe "nãomanual de rotina" (classe IV: por exemplo, ocupações no comércio e de escritório, ou seja, do setor de serviços) e na classe "trabalhadores manuais não-qualificados" (classe VII). Quase não há mulheres empregadoras urbanas ou rurais (respectivamente, classes III e VIII). Em contraste, a maioria dos empregadores urbanos e rurais (classes III e VIII) e dos trabalhadores manuais qualificados (classe VI) são homens. Além disso, os dados mostram que as mulheres foram mais afetadas pela mobilidade estrutural do que os homens. Provavelmente por causa da expansão do setor de serviços (terciário), que contribuiu muito para aumentar a participação das mulheres no mercado de trabalho desde a década de 70.

Conseqüentemente, houve muita mobilidade ascendente para mulheres. Não obstante, esta mobilidade das mulheres não correspondeu à diminuição na mobilidade social dos homens - a mobilidade por troca ou de "circulação" é, em geral, maior para homens do que para mulheres.

(2) Para melhor descrever os contornos da estrutura de classes brasileira, a autora propõe testar três hipóteses clássicas sobre mobilidade social: fechamento social, zona de contenção e contramobilidade. Tendo em vista que os índices de mobilidade absoluta (apresentados acima) descrevem tendências gerais na tabela de mobilidade, e portanto podem levar a interpretações precipitadas sobre os níveis de mobilidade absoluta, tornase necessário definir hipóteses mais precisas sobre os padrões de mobilidade absoluta. De acordo com a hipótese do fechamento social, "o fluxo mais alto de mobilidade acontece entre indivíduos que ocupam posições próximas na estrutura social, 0 que previne a mobilidade de longa distância" (p. 111). Esta tese parece ser válida para 0 caso brasileiro, sendo que as mulheres têm menos chance de passar para classes inferiores do que os homens. A hipótese da "zona de contenção" sugere que há muita mobilidade na fronteira entre ocupações manuais e não-manuais, o que impede a mobilidade de longa distância. Tanto para homens quanto para mulheres, a tese da zona de contenção parece ser verdadeira, ou seja, há muita imobilidade nas classes de profissionais e trabalhadores rurais porque 0 grosso da mobilidade se dá entre trabalhadores manuais e não-manuais próximos na estrutura de classes. Além disso, uma vez no mercado de trabalho, as mulheres têm poucas chances de mudar de classe social. Finalmente, a tese da "contramobilidade" sugere que "0 incremento na mobilidade ascendente via educação em décadas recentes é 'compensado' pelo decréscimo de mobilidade durante a vida produtiva" (p. 122). Em outras palavras, a tese da contramobilidade pressupõe que 0 aumento da mobilidade para a primeira ocupação é compensado por uma "contramobilidade", com a diminuição da mobilidade de carreira. Esta tese parece ser verdadeira para 0 caso dos homens, mas não é plausível para as mulheres. Por exemplo, enquanto a mobilidade intrageracional ascendente tende a diminuir para os homens ao longo do tempo, as mulheres experimentam um padrão inverso, com 0 aumento da mobilidade de carreira.

As análises de Scalon sobre desigualdades de posição - medidas por taxas e índices absolutos de mobilidade - indicam que, em geral, os homens estão em posições melhores do que as mulheres, ou seja, os homens têm ocupações melhores e mudam mais para classes privilegiadas do que as mulheres. Todavia, os dados também 
indicam que as mulheres vêm gradualmente melhorando sua situação no mercado de trabalho brasileiro.

(3) 0 terceiro e principal objetivo do livro é desenvolver um modelo log-linear "topológico" para descrever os padrões de associação entre classes de origem e de destino, ou o grau de fluidez social no Brasil. Este modelo propõe, ainda, testar se os padrões de mobilidade de classe são diferenciados para homens e mulheres.

0 modelo proposto mostra que a estrutura de classes no Brasil é extremamente rígida. $\mathrm{Ou}$ seja, as chances relativas de mobilidade para as classes mais privilegiadas não são, nem de longe, distribuídas igualmente para indivíduos com origem nas diversas classes sociais. Um exemplo assustador é 0 das chances relativas de filhos de trabalhadores rurais (classe IX) alcançarem a classe de profissionais (classe I) em relação às chances que um filho de profissional tem de seguir os passos de seu pai. Um filho de agricultor tem 1.140 vezes menos chances de se tornar um profissional do que o filho de um profissional. E a filha de um agricultor tem 1.462 vezes menos chances de se tornar uma profissional do que a filha de um profissional. Já as chances de 0 filho de um trabalhador não-qualificado (classe VII) - digamos, um porteiro - se tornar um profissional - digamos, um médico é 133 vezes menor do que as chances de um filho de profissional seguir os passos de seu pai. Estes níveis de desigualdade de chances ou de acesso deveriam ser decorados não apenas por todos os estudantes de sociologia, mas também por qualquer pessoa que imagine por uma fração de segundos que o Brasil é o país das oportunidades. É impossivel interpretar a cultura brasileira sem conhecer estes números que nossa colega nos mostra com tanta mestria. Não custa lembrar que em países europeus números semelhantes costumam variar entre 10 e 20, o que é considerado escandaloso. Tanto Scalon quanto eu já pudemos observar como pesquisadores de outros países ficam chocados ao tomar conhecimento dos níveis de desigualdade de acesso no Brasil.

Numa sociedade em que as desigualdades de oportunidade são tão marcadas pelas posições de classe, não surpreende observar que a diferença entre chances relativas de mobilidade não é grande entre homens e mulheres. Na verdade, estas chances são definidas muito mais pelas origens de classe do que pelo gênero da pessoa. Mulheres e homens sofrem terrível e semelhante desigualdade de acesso ou oportunidade.

A leitura dos livros de Pastore e Valle Silva e de Scalon requer atenção, não é leitura fácil. Os autores não oferecem conclusões bombásticas e imediatistas, como por exemplo: o Brasil melhorou, não melhorou, é um país aberto, é um país fechado... Ao invés disto, convidam os leitores não apenas a seguir todos os estágios da análise, como também oferecem chances para que verifiquem a validade das análises passo a passo. Os que aceitarem este convite não se arrependerão. Aprenderão muito sobre metodologia quantitativa, sobre estratificação social, sobre o Brasil, e sobre sociologia.

\section{Referências bibliográficas}

BLAU, Peter e DUNCAN, Otis Dudley. (1967), The American coupational structure Nova York, Willey.

ERICK SO N, Roberte G O LDTHO RPE, John H. (1992), "The CASMIN project and the American dream". European Socidogial Reiew 8: 283306.

FEATHERMAN, D avid L., JO NES, F. Lancastere HAUSER, Robert. (1975), "Assumptions of social mobility research in the U.S.: the case of occupational status". Soial Sidences Research, 4: 329-60.

GIDDENS, Anthony. (1973), The dass structure of the advanced soieties Nova York, Harper and Row.

GOLDTHORPE, John (com Catriona Llewellyn e Clive Payne). (1987), Social mbility and dass struc ture in modem Britain Oxford, Clarendon Press.

GOLDTHO RPE, John e ERICKSO N, Robert. (1993), The constant flux: a study of dass mbility in industrial soieties Oxford, Oxford University Press.

HO UT, Michael. (1989), Following in fathe's foots teps Cambridge, Harvard University Press. 
HOUT, Michael e HAUSER, Robert. (1992), "Symmetry and hierarchy in social mobility: a methodological analysis of the CASMIN model of class mobility". European Soidogical Reviev 8: 239-66.

MARSHALL, Gordon, SWIFT, Adam e ROBERTS, Stephen. (1997), Against the odds: soial dass and social justice in industrial soieties Oxford, Oxford University Press.

PASTORE, José. (1981), Inequality and soial mobility in Brazil. Madison, University of Wisconsin Press.

SO BEL, Michael E. (1983), "Structural mobility, circulation mobility and the analysis of occupational mobility: a conceptual mismatch". Aneican Socidogical Review 48: 721-27.

SO BE L, Michael E., BECKER, Mark P. eMINICK, Susan M. (1998), "Origins, destinations, and association in occupational mobility". American Jarrnal of Sodidogy, 104: 687-721.

WRIGHT, Erick O. (1997), Class counts comparative studies in dass analysis Cambridge, Cambridge University Press.

\section{CARLOSANTONIO COSTA RIBEIRO é} professor de Sociologia do Departamento de Ciências Sociais da Universidade do Estado do Rio de Janeiro (UERJ) e doutorando em Sociologia pela Columbia University.

\section{0 modelo sindical corporativo mudou?}

Adalberto Moreira CARD OSO. Sindicatos, trabalhadares e a coqudude nediberal: a era Vargas acabau? Rio de Janeiro, Fundação Getulio Vargas, 1999. 186 páginas.

Iram Jácome Rodrigues

O ano de 1978 foi fundamental para a ação sindical no Brasil. A sociedade civil foi tomada de surpresa. De repente, os trabalhadores, que raramente eram mencionados nos jornais da chamada grande imprensa, quando muito apenas nos cadernos de economia, passam a ocupar as primeiras páginas de todos os periódicos, bem como 0 noticiário do rádio e televisão. De um momento para outro suas greves são colocadas no centro das atenções políticas do país inteiro.

Defendendo a liberdade e autonomia sindicais, a organização dos empregados nos locais de trabalho, 0 fim do controle do Ministério do Trabalho sobre os sindicatos, 0 direito de greve, a negociação direta entre patrões e empregados, sem a ingerência do Estado, entre outras bandeiras, o Sindicato dos Metalúrgicos de São Bernardo vai despontar e se consolidar no cenário político do final dos anos 70 como o pólo de um sindicalismo que se distanciava cada vez mais do trabalho desenvolvido por aqueles sindicalistas que, tanto no campo conservador quanto nas fileiras da chamada esquerda ortodoxa, não privilegiavam um contato maior com os trabalhadores nas empresas e, além disso, defendiam a permanência do Estado na esfera das relações capital/ trabalho.

É, pois, a partir dos temas relacionados às condições de trabalho e salários, bem como às condições de vida dos metalúrgicos no final da década de 60 e início de 70 que o surgimento dessa nova praxis sindical altera, sobremaneira, a correlação de forças no interior do sindicalismo, resgatando, para os trabalhadores, a luta por direitos a partir do local de trabalho. E isso, sem dúvida, causará um grande impacto no conjunto dos metalúrgicos, no primeiro momento, e pos- 
teriormente em amplas parcelas das classes trabalhadoras.

A passagem de uma luta extremamente defensiva e localizada para uma ação mais ampla, no final dos anos 70 e início dos 80, quando os conflitos começam a eclodir por todos os lados, com greves por categorias, por fábricas, e mesmo greves gerais, foi um marco na história do sindicalismo brasileiro. O verdadeiro ponto de inflexão foram as greves por fábrica. Iniciadas em São Bernardo em maio de 1978, estas se estenderam, em seguida, praticamente pelo país inteiro. Tendo como ponto de partida as paralisações iniciadas em maio de 1978, o novo sindicalismo consolidou um avanço importante na experiência trabalhista em nosso país nestas últimas duas décadas.

Nos anos 90, no entanto, ocorreu uma mudança radical nas demandas do sindicalismo. Em função das transformações na produção, na organização e na gestão do trabalho - a chamada reestruturação produtiva - a agenda sindical voltou-se para o interior da empresa, para a discussão de temas mais diretamente relacionados à problemática do trabalho, seja vinculados à organização e gestão do trabalho, seja relacionados à remuneração variável, como a Participação nos Lucros e Resultados (PLR), ou, ainda, os que dizem respeito à flexibilização da jornada de trabalho, como banco de horas, entre outros.

$\mathrm{Na}$ verdade, este é 0 cerne das preocupações de Adalberto Moreira Cardoso e o fio condutor da análise desenvolvida no livro Sindicatos, trabalhadores e a coquduche nediberal, que reúne trabalhos anteriores do autor. O primeiro capítulo do livro trata da regulação do mercado de trabalho tendo como pano de fundo a questão da estrutura sindical; 0 segundo discorre especificamente sobre o tema da estrutura sindical; 0 terceiro capítulo procura dar conta da discussão da representatividade dos sindicatos no Brasil; já o quarto e quinto capítulos analisam, respectivamente, 0 problema da organização por local de trabalho e a legislação trabalhista.

O tema central do livro é, no entanto, a questão da estrutura sindical. Analisando a trajetória do novo sindicalismo, o autor observa que este "nasceu das entranhas do sindicalismo corporati- vo. Isso explica, sem dúvida, o alto grau de continuidade dessa estrutura, apesar do ímpeto reformador do novo sindicalismo." (p. 34). De outra parte, ressalta que, em certo sentido, as principais demandas do novo sindicalismo, tais como "autonomia sindical ante 0 Estado e os partidos; organização por locais de trabalho; demanda de novos direitos sindicais e trabalhistas [...] foram a fórmula sucinta que fez dessa forma de organização sindical uma novidade completa no cenário das relações industriais no Brasil, apesar de ela estar assentada na estrutura sindical oficial." (p. 35).

Assim, um aspecto enfatizado é o processo de fragmentação e descentralização do sindicalismo em nosso país. A partir dos dados de pesquisa do IBGE, o autor mostra que há fragmentação, mas observa que este fenômeno também significa organização de interesses, e "não apenas fragilização do movimento sindical". Além disso, procura demonstrar que "a Justiça do Trabalho não é o principal agente nas negociações trabalhistas; 0 imposto sindical não é a principal fonte de renda dos sindicatos; os sindicatos não contam (ouso dizer, nunca contaram) com burocracias especializadas; a prestação de serviços não é atividade central nem sequer importante para a maioria dos sindicatos brasileiros [...] 0 sindicalismo brasileiro está se modernizando apear da CLT, contra ela e extravasando-a inteiramente. Não se trata de defendêla, pois, mas de mostrar que ela se tornou incapaz de legislar sobre a realidade que ajudou a configurar, e que os sindicatos estão revelando o caminho para sua renovação." (pp. 43-44; grifos do autor).

Utilizando a pesquisa sindical do IBGE de 1992, Adalberto Cardoso sugere que a fragmentação sindical estaria relacionada com 0 crescimento do número de sindicatos, principalmente nos anos 80; ao mesmo tempo, aventa a hipótese da existência de uma estreita relação entre conjunturas políticas e econômicas e 0 processo de surgimento de novos sindicatos trabalhistas no país. 0 autor aponta para a existência de "uma associação bastante estreita entre 'ebulição social' dos trabalhadores e o ritmo de criação dos sindicatos" (p. 49), mesmo reconhecendo que, muitas vezes, o puro e 
simples surgimento de sindicatos não signifique, necessariamente, uma maior organização por parte dos trabalhadores.

De outra parte, 0 autor discute criticamente a idéia, presente na literatura, de que o sindicalismo brasileiro só vai até a porta da fábrica, reconhecendo que esta forma de tratar a questão estaria correta "apenas em parte". Observa ser "muito provável que permaneça diminuto 0 [seu] poder de intervir no cotidiano fabril. Mas o enraizamento nos locais de trabalho vem-se ampliando nos últimos anos" (p. 52). Utilizando os indicadores de representação por local de trabalho (p. 53), a partir de dados de pesquisa do IBGE, Adalberto Cardoso procura demonstrar que estaria havendo um crescimento acentuado da representação por local de trabalho no Brasil: "Tomando-se os sindicatos de empregados urbanos, quase metade tinha delegados sindicais em 1991. Entre os sindicatos de trabalhadores rurais, esse percentual excedia os $50 \%$. Em termos médios, para cada 179 empregados urbanos era possível encontrar um delegado sindical, relação que é tanto maior quanto menores as empresas." (p. 52).

O livro também trata de temas como a Justiça do Trabalho, o imposto sindical, a burocracia nos sindicatos, assistencialismo etc. Cardoso chama a atenção para 0 fato de "que a participação dos dissídios coletivos no total das negociações empreendidas entre sindicatos urbanos foi de menos de $32 \%$ em termos globais, e de menos de $31 \%$ se considerarmos apenas os sindicatos de emprega dos urbanos Mais importante do que isso, as sentenças nomativas representaram não mais que $5,2 \%$ dos resultados totais e menos de $5 \%$ entre os empregados urbanos." (p. 56). Já no que diz respeito ao imposto sindical, o estudo aponta que, em 1992, "48,5\% dos sindicatos nacionais tinham $30 \%$ ou menos de sua receita compostos pelo imposto sindical". Neste caso, a conclusão do autor é "que para metade dos sindicatos brasileiros existentes em 1992 o imposto não era uma fonte de renda insubstituível, isto é, com seu fim esses sindicatos não estariam condenados ao desaparecimento" (p. 63). Utilizando dados de 1991, ele mostra que, "em média, a contribuição associativa (voluntária) respondia por $47 \%$ da receita sindical.
Essa participação varia muito pouco segundo 0 tamanho dos sindicatos e segundo o número de associados. [D efendo] a seguinte afirmação: os sindicatos no Brasil são finaniados, predominantemente, palas contribuiçóes assodativas 0 imposto sindical perde crescente espaço, mesmo diante da virtual explosão no ritmo de criação de sindicatos observada no final dos anos 80." (p. 68; grifos do autor).

No que diz respeito à prestação de serviços, os dados da pesquisa apontam, por exemplo, que $78 \%$ dos sindicatos no país não têm médicos e cerca de $70 \%$ não tinham dentistas. Além disso, embora, pela legislação atual, os sindicatos devessem prestar assistência jurídica tanto a filiados quanto a não filiados, "apenas $25 \%$ deles tinham advogados em seu staff. Finalmente, poucos sindicatos empregavam contadores, e menos ainda tinham assessores sindicais em seus quadros" (p. 72). Vale dizer, estes dados estariam corroborando a idéia de que, para a grande maioria dos sindicatos, a questão da prestação de serviços não é predominante.

Outro tema abordado no estudo refere-se à taxa de sindicalização. Apoiando-se em dados do IBGE, o autor procura demonstrar que se levarmos em conta a população economicamente ativa (PEA) com carteira assinada na cidade e no campo, mais os funcionários públicos - que passaram a ter direito à sindicalização após a Constituição de 1988 - , o Brasil possuiria um número elevado de empregados sindicalizados: em 1992, 1993 e 1995 a taxa era de cerca de 30\%; em 1988, de aproximadamente 28\%. Esta taxa seria "equivalente à encontrada na Alemanha, Itália e no Canadá; superior à encontrada nos Estados Unidos, Japão, França, Países Baixos e Suíça; e inferior apenas à de países com forte tradição social-democrata." (p. 85; dados de 1989).

Um argumento que permeia todo o trabalho é, em certa medida, a idéia de que, a despeito desta estrutura sindical corporativa, e em decorrência da exclusão social - uma espécie de marca registrada da sociedade brasileira - , os sindicatos têm desempenhado um papel de "escolas" de cidadania para uma parcela significativa dos trabalhadores no Brasil. Ou seja, "a extensão da malha sindical ao 
interior da floresta amazônica, aos sertões nordestinos, às fazendas gaúchas foi a extensão de direitos a populações inteiras de trabalhadores [que estavam anteriormente] à margem inclusive da 'cidadania regulada'. Em suma, a exclusão social é tão premente e tão extensa no país que levar aos excluídos relações 'arcaicas' de trabalho [...] é um avanço sem precedentes: é levar 0 Estado a regiões onde o Estado não comparece sequer como polícia, que dirá como agente de direito universal." (p. 78).

Isso quer dizer que o modelo sindical corporativo não é mais o mesmo? A resposta é, a um só tempo, sim e não. Se olhamos para aquelas instituições sindicais mais representativas dos trabalhadores brasileiros, certamente a resposta é afirmativa. Quando, no entanto, observamos os pequenos sindicatos, sem representação real da sua base, a resposta é negativa. Em face da heterogeneidade da força de trabalho em nosso país, poderíamos dizer que existem vários padrões de ação sindical. De um lado, um sindicalismo que tem algum poder de negociação com 0 empresariado, que possui certa organização nos locais de trabalho, enfim, que tem uma maior proximidade com seus representados; de outro, uma ação sindical que está muito distante dos trabalhadores e cuja prática tem uma eficácia muito pequena numa conjuntura em que os trabalhadores, em larga medida, estão na defensiva. Por exemplo, 0 fato de existir um delegado sindical para 179 empregados urbanos não permite afirmar que tenha havido uma ampliação do enraizamento da organização trabalhista nos locais de trabalho. Um aspecto que é importante ressaltar é que estes delegados não são eleitos e, em muitos casos, a atuação destes empregados no interior das empresas na defesa dos interesses dos trabalhadores é praticamente nula.

A tese central do autor, no entanto, está correta se levamos em conta, tão-somente, aquela parcela que é preponderante no interior do sindicalismo da Central Única dos Trabalhadores e entre aqueles sindicatos mais fortes - e são poucos que estão filiados à Força Sindical. Enfim, para aquele setor sindical que realmente conta, pode-se dizer que houve uma renovação sindical a despeito da estrutura sindical corporativa. No entanto, a real democratização das relações de trabalho no Brasil só chegará com o completo desmantelamento dos elementos corrosivos do nosso modelo corporativo, tais como a unicidade sindical, 0 monopólio da representação, 0 papel ainda desempenhado pela Justiça do Trabalho e as contribuições compulsórias. Nesse aspecto, a análise desenvolvida por Adalberto Cardoso no capítulo 4, que trata da organização no local de trabalho, é extremamente atual. Sem uma ampla organização trabalhista no interior das empresas é impossível se pensar em democratização das relações capital/ trabalho em nosso país. Vale dizer, mesmo com as mudanças ocorridas no modelo sindical corporativo, no sentido de sua "renovação" a partir de dentro, existem vários óbices que devem ser ultrapassados para que a democracia possa chegar a contento nas relações trabalhistas.

A experiência da CUT é emblemática nesse sentido. A Central nasceu do chamado novo sindicalismo, que baseava sua ação numa forte contestação à estrutura sindical corporativa, mas aos poucos esse aspecto da identidade atista foi desaparecendo e dando lugar a uma certa adaptação ativa a este modelo. Esse processo teria levado a uma acomodação ao corporativismo, que se expressa, por exemplo, pela fraca penetração desse padrão sindical nas empresas, salvo algumas exceções. Outra questão relevante para a ação sindical e que ainda não foi resolvida é o tema da organização por local de trabalho. Houve algum avanço nesses anos, mas ainda há muito por fazer neste terreno. A esmagadora maioria do sindicalismo ligado à CUT não tem uma implantação muito expressiva nos locais de trabalho. Nesse aspecto, a situação no âmbito da Força Sindical é ainda pior. Além disso, o contrato coletivo de trabalho é uma das condições básicas para que a organização por local de trabalho possa se desenvolver. Ou seja, é necessário, de um lado, a liberdade de organização nos locais de trabalho e, de outro, a negociação direta entre empregados e empregadores, sem a tutela do Estado.

0 mérito do livro de Adalberto Cardoso é, a partir de um amplo levantamento de dados e de uma leitura atenta da bibliografia sobre 0 mundo do trabalho, apontar algumas pistas sobre o signi- 
ficado da ação sindical no Brasil nestas duas últimas décadas e, ao mesmo tempo, chamar a atenção para os aspectos de ruptura/ continuidade e/ ou renovação/ inércia organizacional do modelo sindical corporativo, explicitando um conjunto de questões que estão subjacentes no debate acadêmico mas que, não raro, "teimam" em não vir à tona. Aliás, a idéia de renovação e/ ou inércia organizacional é um veio fértil para a apreensão da ação trabalhista nestas duas últimas décadas no Brasil.

IRAM JÁCOME RODRIGUES é professor do Departamento de Economia da USP.

\section{"Fazer viver e deixar morrer": as sociedades modernas e a tipologia de seus poderes}

Michel FOUCAULT. Em defesa da soiedade Tradução de Maria Ermantina Galvão. São Paulo, Martins Fontes, 1999. 382 páginas.

\section{Márcio Alves Fonseca}

Qual poderia ser 0 objeto de um livro em que são discutidos temas que vão da crítica aos saberes ditos "científicos" à análise do modelo de poder representado pela soberania, da abordagem de diferentes formas de escrita da história à discussão do tema da guerra entre grupos e "nações", da análise dos mecanismos e estratégias de poder na atualidade à descrição dos fundamentos do racismo? Talvez seja um livro não de um único objeto, mas de muitos. Talvez não seja exatamente um livro, apesar de ser apresentado como tal, pois trata-se propriamente de um curso de Michel Foucault, ministrado em 1976. Em defesa da sociedade é o primeiro curso do filósofo a ser publicado, dentre os treze que ministrou como professor do Collège de France entre 1970 e 1984.

Seguindo a forma de um curso, o texto divide-se em 11 aulas (que eram ministradas semanalmente entre os meses de janeiro a março de cada ano), em que se deve procurar menos pelo rigor na construção de uma tese central que pelos movimentos de formulação de uma série de problemas e questões. 0 que não significa, de forma alguma, falta de consistência teórica. Ao contrário, nas aulas que compõem o curso o autor faz uma análise aprofundada dos temas já citados, e de vários outros, fundamentando-se numa vasta bibliografia de referência e preocupando-se em estabelecer correlações, demonstrar encadeamentos. 0 leitor não terá dificuldades em localizar-se quanto ao problema abordado em cada aula, inclusive em sua continuidade ao desenvolvimento da aula anterior. Neste aspecto, percebe-se a acuidade do senso didático-pedagógico do "professor" Michel 
Foucault. Observa-se apenas que o livro deve ser lido atentando-se para 0 ritmo que lhe é próprio, 0 ritmo de um curso. E neste sentido, talvez mais do que lido, este trabalho deva ser "ouvido", e suas reflexões e provocações recebidas como que no âmbito de uma discussão.

O curso foi ministrado entre a publicação de Vigar e punir (1975) e de A vantade de saber (1976). Nos dois livros, o que está em jogo é 0 tema do poder em seus mecanismos de intervenção e de constituição da subjetividade moderna. É igualmente a discussão acerca de um modelo estratégico para a análise das relações de poder que está presente no conjunto das aulas de Em defesa da sociedade Logo no início do texto, a referência à atividade genealógica como a atividade que faz os saberes locais, descontínuos e nãolegitimados, atuarem contra os efeitos de poder centralizadores de um discurso científico, que requer para si o estatuto de conhecimento verdadeiro, serve para localizar o curso em relação ao pensamento do autor. Trata-se de perguntar, em seus mecanismos, seus efeitos e suas relações, pelos dispositivos de poder que são exercidos nos diferentes domínios da sociedade. Em face das análises do poder deduzidas da economia, como aquela presente no pensamento político liberal dos contratualistas do século XVIII, bem como na concepção marxista no século XIX, a possibilidade de uma análise não-econômica do poder recai sobre duas hipóteses: o poder seria pensado em termos de mecanismos de repressão ou sua rede de inteligibilidade seria 0 enfrentamento belicoso das forças. De onde se distinguem dois modelos de análise do poder: 0 esquema jurídico (fundado na oposição contrato/opressão) e 0 esquema guerra-repressão (fundado na oposição luta/ submissão). Em relação a estes dois modelos, as pesquisas do autor nos anos precedentes teriam se realizado justamente em torno do esquema guerra-repressão. Uma vez que tal modelo ainda não estaria suficientemente elaborado, é seu desenvolvimento que está em questão no presente curso. Em outros termos, o problema que percorre Em defesa da sociedade é o de se saber em que medida a guerra pode servir como princípio de análise das relações de poder.
Para 0 autor, o modelo jurídico da soberania não está apto para uma análise da multiplicidade concreta das relações de poder que caracteriza a época moderna. Isto porque este modelo apresenta-se segundo uma tríplice primitividade. Ele pressupõe a universalidade do sujeito, a unidade do poder e o elemento fundador da lei. Não há teoria da soberania sem sujeito, unidade do poder e lei. Ora, uma análise das relações de poder que esteja liberada deste modelo da soberania implica que a tripla referência ao sujeito, à unidade do poder e à lei seja substituída por uma referência ao que 0 autor entende por "operadores de dominação". São as relações de dominação que devem ser a via de acesso a uma análise do poder. E a guerra, o combate, o enfrentamento é que podem valer como matriz para o estudo das técnicas de dominação. Inversão, portanto, da proposição de Clausewitz, na medida em que se trata de pensar que a "política é a guerra continuada por outros meios".

Daí a análise que Foucault fará, nas aulas que compõem a maior parte do curso, de um discurso histórico a que chama de "estranho" e "novo". Discurso que aparece depois do fim das guerras civis e religiosas do século XVI e que está claramente formulado no início das lutas políticas inglesas do século XVII; que está presente também na França, no final do reinado de Luís XIV, em lutas políticas diferentes das que esteve ligado na Inglaterra; que está presente igualmente entre os biólogos racistas e eugenistas do fim do século XIX. Um discurso histórico-político das sociedades, muito diferente do discurso filosófico-jurídico que se costumava fazer até então. Um discurso sobre a guerra entendida como relação social permanente e como fundamento de todas as relações de poder. No seio deste discurso histórico novo, a guerra não está afastada do poder político. É a ela, ao contrário, que se deve perguntar acerca da estrutura jurídica do poder, dos Estados e das sociedades, pois é ela que preside seu nascimento: "0 direito, a paz, as leis nasceram no sangue e na lama das batalhas" (p. 58). Mas o direito, a paz e a lei não representam 0 final dos enfrentamentos a que devem sua origem. A guerra continua a ser 0 motor das instituições e da ordem. 
A importância deste discurso histórico está ligada ao fato de tratar-se de um discurso de perspectiva. 0 sujeito que fala ocupa sempre uma posição, está necessariamente de um lado ou de outro numa situação, não se constituindo, portanto, num sujeito universal neutro. Daí ser o primeiro discurso na sociedade ocidental, desde a Idade Média, que pode ser chamado rigorosamente de histórico-político. Nele, a inteligibilidade da história se faz segundo um eixo ascendente, uma vez que procura, no entrecruzamento dos corpos, das paixões e dos acasos, a trama permanente da própria história e das sociedades. $\mathrm{Na}$ base da história está uma irracionalidade fundamental. Por fim, é um discurso que se desenvolve por inteiro na dimensão histórica. A história não tem seu sentido dado por uma instância diferente (superior, transcendente) daquela dos gestos e das relações que a compõem.

Se o discurso histórico tradicional desempenha 0 papel de ligar os homens ao poder por meio da lei, ou seja, de ser um intensificar do poder a partir da representação da grandeza dos acontecimentos e do caráter ininterrupto do direito soberano que o caracterizam, o discurso histórico desempenhará uma função de contra-história. Será 0 discurso das raças, do afrontamento das raças em oposição ao discurso da soberania. E neste sentido, ele representa, para 0 autor, a primeira história não-romana ou anti-romana que o Ocidente conheceu. Em seu interior, a função da memória não será assegurar a manutenção da lei e a majoração do poder soberano, mas trazer à tona algo de negligenciado e mascarado, algo que seria 0 enfrentamento das forças, o elemento mesmo constitutivo da história.

A primeira preocupação do autor, ao discutir alguns exemplos deste discurso histórico que faz da guerra 0 analisador das relações de poder, consiste em colocar de lado aqueles pensadores tradicionalmente vistos como sendo os teóricos da guerra. Foucault refere-se sobretudo a Maquiavel e a Hobbes. Especialmente este último aparece normalmente como aquele que teria colocado a guerra no fundamento das relações políticas. Para Foucault, no estado de natureza de Hobbes não há batalhas, há representações. Representações calcu- ladas, manifestações enfáticas de vontade e táticas de intimidação entrecruzadas. A guerra de todos contra todos seria uma guerra da igualdade, que se daria na ordem das representações, e não na ordem do enfrentamento das forças reais. Ao invés de ser o teórico das relações entre a guerra e 0 poder político, Hobbes torna a guerra, como realidade histórica, como manifestação de força efetivamente manifesta no conflito, indiferente à gênese da soberania, que se forma antes pela vontade daqueles que têm medo.

Em oposição ao pensamento de Hobbes, pode-se então fazer referência a um discurso diferente, que aparece quase como o adversário polêmico deste pensamento que exclui a guerra e que é o discurso da luta e da guerra civil permanentes. Um discurso que é, no fundo, uma espécie de jogo discursivo, pois se constitui numa certa estratégia teórica que faz funcionar 0 saber histórico no interior das lutas políticas. É precisamente uma série de exemplos deste discurso de um "historicismo político" que será objeto de análise de grande parte das aulas que compõem Em defesa da soie dade $O$ que nelas está em jogo, portanto, é a análise de um discurso histórico-político que expõe "a guerra como traço permanente das relações sociais, como trama e segredo das instituições e dos sistemas de poder" (p. 132).

Assim decorre a abordagem feita pelo autor do discurso histórico da nobreza reacionária na França do final do século XVII. No centro desta abordagem está a obra de Boulainvilliers sobre as instituições políticas francesas, especialmente um de seus escritos, marcado por um forte cunho pedagógico-político, na medida em que se destina a apresentar e criticar os relatórios sobre um estudo geral da situação, da economia, das instituições e dos costumes da França, encomendado por Luís XIV para instruir seu sucessor, o então duque de Borgonha. O saber contido nestes relatórios seria uma espécie de saber do Estado sobre o Estado, uma vez que os encarregados em fornecer e organizar as informações neles contidas tinham sido os próprios funcionários da administração pública. Em seu texto, Boulainvilliers protesta justamente contra 0 fato de que 0 saber dado ao rei seja um saber fabricado pela máquina administra- 
tiva e, a partir de tal crítica, procura fazer valer as teses favoráveis à nobreza contra este tipo de "saber do rei". Trata-se de despertar a memória dos nobres e do próprio monarca a fim de se reconstituir 0 "justo saber do rei". Em tal reconstrução, os dois maiores inimigos a se enfrentar são os discursos representados pelo saber jurídico e pelo saber econômico, os saberes do tribunal e da repartição pública. E o saber que deve substituir estes dois é precisamente 0 saber da história. No discurso histórico, o sujeito que fala não está em posição de exterioridade em relação àquilo que narra, mas é 0 personagem central da narração. 0 sujeito deste novo discurso histórico fala em primeira pessoa e constitui-se naquilo que 0 vocabulário da época designa por "nação", no sentido de uma sociedade, um grupo que tem seus costumes, seus usos e sua regularidade estatutária. A nobreza seria, assim, "uma nação em face de muitas outras que circulam no Estado e se opõem umas às outras" (p. 161).

Com o discurso histórico de Boulainvilliers define-se 0 princípio do caráter relacional do poder (o poder não é uma propriedade, mas uma relação), e a relação de força e 0 jogo de poder tornam-se a substância mesma da história, diferentemente de Maquiavel, para quem a história seria um lugar de exemplos, um local em que se encontram modelos táticos para o exercício do poder. Em Boulainvilliers, a narração histórica e 0 cálculo político são uma única coisa. Tomar a palavra no domínio da história não significa apenas descrever uma relação de força, mas implica alterar, intervir nas relações de força. Para Foucault, com esta nova forma de discurso histórico "temos, pela primeira vez, um continuum histórico-político" (p. 202). Noções fundamentais que permitem ao autor, em um momento da oitava aula do curso (pp. 205223), realizar o que chama de duas digressões, nas quais vai definir em que sentido pode-se entender seu trabalho como um tipo de historicismo e, num segundo conjunto de observações, discorrer sobre os mecanismos de disciplinarização dos saberes colocados em funcionamento no século XVIII, possibilitando-o diferenciar os eixos em que se situam uma "história das ciências" e uma "genealogia dos saberes". Em relação ao saber histórico, estes dois eixos seriam expressos, respectivamen- te, por um saber efetivamente disciplinarizado sob a forma da disciplina histórica e por uma consciência histórica polimorfa, combatente, que seria a outra face da consciência política.

O mesmo tipo de discurso histórico, formado em torno da reação nobiliária do começo do século XVIII, será reutilizado no interior de um projeto revolucionário burguês e também será, em certa medida, apropriado ou controlado pelo poder monárquico. 0 que demonstra tratar-se de um discurso que circula entre as personagens das quais relata a história. Discurso, portanto, de perspectiva, que pode ir da direita para a esquerda e estar presente nas lutas de diferentes grupos políticos, na medida em que seu sujeito é sempre uma "nação" que fala de dentro da história e que se toma por objeto da própria narração. Assim, 0 autor passa a estudar como o discurso histórico se generaliza como tática discursiva, tornando-se utilizável em diversas lutas políticas.

Entretanto, o elemento da guerra, funcionando como rede de inteligibilidade da história, será paradoxalmente "imunizado" no momento da Revolução, no interior do próprio discurso histórico. Foucault fala em um "emburguesamento" deste discurso, que consiste no deslocamento do papel da guerra em seu interior: de constitutivo da história para protetor e conservador da sociedade, de "condição de existência da sociedade e das relações políticas" para "condição de sua sobrevivência em suas relações políticas" (p. 258). A descrição deste deslocamento no interior do discurso histórico dá-se com a análise da reelaboração política da noção de "nação", realizada pelo pensamento burguês, a partir das dificuldades da burguesia em utilizar este discurso como arma nas lutas políticas. O exemplo desta transformação da idéia de nação discutido no texto é a obra de Sieyès sobre 0 Terceiro Estado. Em Sieyès, a nação será definida pela sobreposição de dois conjuntos de condições. Para haver uma nação é necessário que exista uma lei comum (Estado jurídico) e a conjugação de trabalhos (agricultura, artesanato, comércio etc.) e funções (exército, Igreja, administração etc.). Estas condições estariam presentes no Terceiro Estado e somente este será a nação. A idéia de nação é, então, reelaborada em função de uma 
referência essencial ao Estado. Este discurso político será a matriz de um discurso histórico que, para 0 autor, se reaproxima do Estado e, desta forma, deixa de ter uma função antiestatal. A partir desta nova forma do discurso histórico, a idéia de guerra que nele aparece é a de uma guerra interna travada "em defesa da sociedade" contra os perigos que nascem em seu próprio corpo. Todas as batalhas dão lugar a uma única, aquela que a nação (Estado) realiza continuamente em seu próprio interior em nome da sociedade. A "guerra das raças" dará então lugar a algo muito diferente, 0 racismo.

Este é o quadro a partir do qual pôde se constituir, na época moderna, uma biopolítica. Em seus domínios não está mais em jogo um direito de vida e de morte sobre os indivíduos, caracterizador da teoria clássica da soberania e que se traduzia, concretamente, pelo poder do soberano em "fazer morrer e deixar viver". Com a tomada da "vida" como objeto de agenciamento do poder, a época moderna opõe ao velho direito de vida e morte da soberania um outro direito ou, antes, um poder de "fazer viver e deixar morrer".

No plano, não de uma teoria política, mas dos mecanismos e das técnicas de poder, já se vê aparecer uma tecnologia disciplinar dos corpos nos séculos XVII e XVIII. Trata-se aí de um mecanismo de poder centrado no corpo individual, em sua distribuição, sua análise, seu exercício, sua conexão a outros corpos. A partir da segunda metade do século XVIII configura-se uma tecnologia que não exclui a disciplinar mas que se aplica a uma superfície diferente, aquela da multiplicidade dos homens como seres vivos, multiplicidade portadora de fenômenos próprios à vida, como 0 nascimento, a doença, a produção, os acidentes, os efeitos do meio, a morte. Com a biopolítica há o aparecimento da população, deste corpo múltiplo, como foco principal das estratégias de poder. Os fenômenos tomados em consideração são os fenômenos coletivos, que se tornam pertinentes para uma massa e em face dos quais se trata de estabelecer mecanismos reguladores, a fim de fixar, em meio a seu campo aleatório, uma certa média ou equilíbrio.

A aula final (pp. 285-315) de Em defesa da sociedade constitui-se numa importante explica- ção das especificidades e da maneira pela qual se articulam as duas tecnologias de poder que se sobrepõem nas sociedades modernas: a tecnologia do adestramento disciplinar e a tecnologia seguracional-reguladora, as disciplinas e 0 biopoder. São dois conjuntos de mecanismos que, ao invés de se excluírem, ajustam-se, acomodam-se um sobre o outro. Como exemplos de domínios em que pode ser percebida claramente esta acomodação, Foucault discute a forma da cidade operária, tal como se dá no século XIX, e o domínio representado pela sexualidade no mesmo período. Partindo de tais análises, mostra que o elemento que circula entre uma tecnologia do corpo e uma tecnologia da população é a norma. "A norma é o que pode tanto se aplicar a um corpo que se quer disciplinar quanto a uma população que se quer regulamentar." (p. 302). Ela permite, ao mesmo tempo, controlar a disciplina dos corpos e os acontecimentos aleatórios de uma população. Estamos, para Foucault, na era do biopoder. Nela, o poder toma a vida como tema, o que significa que seus mecanismos cobrem a superfície que vai do orgânico ao biológico, do corpo à população.

Nas sociedades da normalização (disciplinar e reguladora), que têm na vida seu objeto de poder mais importante, o velho "direito de matar" assume uma forma bastante curiosa. A forma de se exercer 0 poder de matar em um sistema político centrado no biopoder é o racismo. Pelo racismo, introduz-se no domínio contínuo da vida o corte entre aquele que deve viver e aquele que deve morrer. Com 0 racismo, o tema da guerra das raças é inteiramente substituído pela idéia de que "a morte do outro, a morte da raça ruim, da raça inferior (ou do degenerado, ou do anormal), é o que vai deixar a vida em geral mais sadia; mais sadia e mais pura." (p. 305).

A guerra assume, então, uma nova forma. Ela consistirá não somente em destruir 0 adversário político, mas especialmente em destruir a raça inferior. Ela consistirá ainda num meio de regenerar a própria raça, na medida em que a morte de muitos desta raça a purificaria. $\mathrm{E}$ a sociedade nazista aparece, assim, como o exemplo histórico mais surpreendente de um tipo de sociedade em que 0 poder de matar atravessa todo 0 corpo social. Para Foucault, não houve sociedade mais 
disciplinar e mais seguracional que aquela projetada pelos nazistas. Daí o Estado nazista conjugar, ao mesmo tempo, ainda que aparentemente de forma paradoxal, uma espécie de generalização dos procedimentos de uma biopolítica e do direito soberano de matar.

A expressão que serve de título para o curso de 1976 não significa, como uma leitura desavisada poderia dar a entender, uma espécie de divisa, uma palavra de ordem, dada em nome de uma sociedade como a nossa, que precisaria ser defendida. Em dfesa da sociedade é antes uma expressão (ou um livro) que denuncia os mecanismos de uma biopolítica no interior da qual o discurso que reclama a proteção da sociedade e da vida representa, ao mesmo tempo, a forma mais explícita de falar de seus procedimentos (em nome da sociedade exercita-se 0 poder de vida e de morte) e a forma mais discreta de ocultar seus resultados (afinal, em tudo isto trata-se de "defender a sociedade"). Uma vez mais, o pensamento de Michel Foucault nos apresenta instrumentos teóricos importantes, em certa medida novos, para um olhar crítico sobre nosso presente, sobre as sociedades que formamos. É o que parece podermos encontrar neste livro, que inaugura uma série de trabalhos ainda inéditos e que, certamente, muito têm a dizer.

\section{MÁRCIO ALVES FONSECA é professor do Departamento de Filosofia da PUC-SP.}

